\title{
Qualitative evaluation of the menu and plate waste in public day care centers in São Paulo city, Brazil
}

\author{
Avaliação qualitativa do cardápio e desperdício \\ de alimentos em creches públicas do município \\ de São Paulo
}

Giovana LONGO-SILVA ${ }^{1,2}$

Maysa TOLONI ${ }^{1,2}$

Sara RODRIGUES 2

Ada ROCHA

José Augusto de Aguiar Carrazedo TADDEI'

A B S T R A C T

\section{Objective}

This study assessed menu quality and plate waste in public day care centers of São Paulo (SP), Brazil.

\section{Methods}

This cross-sectional study collected data from the nurseries of seven day care centers, totaling 366 children aged 12 to 36 months. Each day care center was assessed for three days, totaling 42 days and 210 meals. Menu quality was assessed by the Qualitative Analysis of Menu Preparations method (Análise Qualitativa das Preparações do Cardápio), adapted for day care centers, which provides nutritional and sensory criteria. Food waste was determined by the Plate Waste-Ingestion Index.

\section{Results}

The supply of vegetables was inadequate in more than $90 \%$ of the days, and the amount of leafy vegetables and high-sulfur foods met the recommended amounts on $50 \%$ of the days. The supply of sweets and foods containing trans fatty acids was considerable. The Plate Waste-Ingestion Index for daycare centers varied from $25 \%$ to $43 \%$, and the Plate Waste-Ingestion Index for food items varied from $11 \%$ to $47 \%$.

${ }_{1}^{1}$ Universidade Federal de São Paulo, Escola Paulista de Medicina, Departamento de Pediatria. R. Loefgreen, 1647, 04040-032, São Paulo, SP, Brasil. Correspondence to/Correpondencia para: JAAC TADDEI. E-mail: <ieddat.taddei@gmail.com>. 2 Universidade do Porto, Faculdade de Ciências da Nutrição e Alimentação. Porto, Portugal.

Apoio: Coordenação de Aperfeiçoamento de Pessoal de Nível Superior/Programa Institucional de Bolsas de Doutorado Sanduíche no Exterior (Processos no 9029-11-7 e no 9032-11-8). 
136 | G LONGO-SILVA et al.

\section{Conclusion}

The preparations served and serving sizes clearly need to be reviewed, and new menu creation strategies are needed to control food waste.

Indexing terms: Child day care centers. Food quality. Menu planning. School feeding. Waste of water.

\section{R E S U M O}

\section{Objetivo}

Avaliar qualitativamente o cardápio e o desperdício de alimentos em creches públicas de São Paulo (SP).

\section{Métodos}

Este estudo é transversal e os dados foram coletados nos berçários de 7 creches, que atendiam 366 crianças entre 12 e 36 meses. Cada creche foi avaliada durante 3 dias, totalizando 42 dias e 210 refeições. A qualidade do cardápio foi avaliada segundo o método Análise Qualitativa das Preparações do Cardápio, adaptado à realidade de creches, que estabelece critérios nutricionais e sensoriais. Foi avaliado o desperdício de alimentos pelo Índice de Resto-Ingestão.

\section{Resultados}

Os resultados refletiram que a oferta de legumes e verduras foi insuficiente em mais de $90 \%$ dos dias e, a quantidade de folhosos e alimentos ricos em enxofre foi compatível com o recomendado em metade dos dias, sendo expressiva a oferta de doces e alimentos contendo ácidos graxos trans. O Índice de Resto - Ingestão variou de $25 \%$ a $43 \%$ nas creches e de $11 \%$ a $47 \%$ nos alimentos analisados.

\section{Conclusão}

Evidencia-se a importância de revisão das preparações servidas e porcionamento dos alimentos, sendo necessária a adoção de novas estratégias na elaboração dos cardápios, visando o controle do desperdício alimentar.

Termos de indexação: Creches. Qualidade dos alimentos. Planejamento de cardápio. Alimentação escolar. Desperdício de alimentos.

\section{N T R O D U CT IO N}

Children's growth and development are not only influenced by appropriate nutrition but also by the establishment of healthy food preferences and eating behaviors, built daily at home and day care centers, in the context of food selection, preparation and supply ${ }^{1}$.

In Brazil, more than two million children are enrolled in day care centers, also known as Child Education Centers (Centro de Educação Infantil-CEI), where they stay from 10 to 12 hours a day and receive five meals a day ${ }^{2}$. All CEI children are covered by the National School Food Program (Programa Nacional de Alimentação Escolar - PNAE) which establishes that menus should provide $70 \%$ of the nutritional requirements of the children who stay at CEl full time ${ }^{3}$. A social investment of $R \$ 150$ million is needed to feed the two million children enrolled in day care centers ${ }^{4}$.
Despite the numerous programs and guidelines that aim to protect children at school, studies around the world show that it is very challenging to meet the proposed norms, often resulting in inadequate nutritional supply ${ }^{5,6}$.

Given the multimillionaire PNAE investment, it is important to investigate and quantify plate waste, since it affects the cost-benefit of the served meals and calls attention to possible failures in menu creation, food selection and preparation, and the individual portion size used in the facility ${ }^{7}$.

Brazil is one of the ten countries that most waste food, discarding annually the equivalent of $\mathrm{R} \$ 12$ billion, which is enough to feed roughly $\mathrm{R} \$ 30$ million people, or eight million families ${ }^{8}$.

The waste chain extends from harvest to the consumer's table, where waste plate-ingestion is the ratio between the food left on the plate by 
the consumer and the amount of food offered. In healthy populations, the acceptable plate waste limit is $10 \%{ }^{9}$.

Poulain \& Proença ${ }^{10}$ argue that for a food to sustain life, it needs not only nutritional quality, expressed by its carbohydrate, protein, fat, vitamin and mineral contents, but also familiarity and acceptance by the individual and social group. Food should have four essential functions: nutritional, hygienic, hedonic and social. Hence, aspects such as taste, color, shape, aroma, texture, temperature, serving time, and eating environment, among others, are components that need to be taken into account by nutritional approaches and assessments of meal acceptance.

Therefore, Veiros \& Proença11 developed the method (Avaliação Qualitativa das Preparações do Cardápios - AQPC) for analyzing menu quality in terms of menu items and their nutritional and sensory aspects. The method was adapted by Menegazzo et al. ${ }^{12}$ to the CEl reality according to the PNAE and Guia Alimentar para a População Brasileira ${ }^{3,13}$.

With this context in mind, the objective of the present study was to make a qualitative assessment of the nutritional and sensory aspects of day care center menu preparations and quantify the plate waste of children that attend public day care centers in the municipality of São Paulo (SP), Brazil.

\section{METHODS}

This study is part of the project "Efficient Day care Center Project (Projeto Creche Eficiente): Impact of training public/philanthropic day care center educators on hygiene and dietary practices and on suckling infants' health and nutrition", which aimed to train, improve and update daycare center educators on the health and nutrition care given to suckling infants and assess the knowledge they gained with respect to their work. Day care center selection and the assessment criteria are described in another publication ${ }^{14}$. Of the eight selected day care centers, one was excluded because it was not interested in participating in the study during the collection period of the data presented here.

The present study is a cross-sectional study done in the 14 nurseries of the selected day care centers. Data were collected from September to December 2010 by four graduate nutrition students of the Universidade Federal de São Paulo (Unifesp).

All day care centers that participated in this study has two nurseries (Nursery I and II) that run full time from Monday to Friday and serve five meals a day, namely breakfast, mid-morning snack, lunch, mid-afternoon snack and supper.

The menus of the meals served in the 14 nurseries of the selected day care centers were assessed on three nonconsecutive weekdays, corresponding to 42 assessed days and 210 meals.

Menu quality was assessed by the AQPC method adapted to $C E I$ reality ${ }^{12}$, which considers eight assessment criteria:

1. Presence of fruits and fruit juices: according to the recommendations, at least three fruit servings should be consumed per day ${ }^{13,15}$. since children are also recommended to have one full meal at home ${ }^{3}$, two fruit and/or natural fruit juice servings was considered adequate.

2. Presence of vegetables: analyzed in the same way as fruits since at least three vegetable servings should be consumed per day ${ }^{13,15}$. Two servings was considered adequate since that the child should have a third serving at home. Soups, chicken soup, pies and cakes, among others, that did not have a vegetable as the main ingredient were not counted.

3. Presence of raw leafy vegetables: at least one serving of raw leafy greens was considered adequate ${ }^{12}$.

4. Color monotony: only lunch and supper were assessed since the other meals consisted of only two preparations with no variations. This 
criterion was considered appropriate when at least $50 \%$ of the foods or preparations had different colors.

5. Presence of high-sulfur foods: since high-sulfur foods produce flatulence that may cause gastrointestinal discomfort and nuisance in the child ${ }^{16}$, side dishes and salads were analyzed. This item was considered adequate when there was at most one high-sulfur food or preparation in the meal. The foods included in this assessment were avocado, chard, celery, peanuts, sweet potato, garlic, onion, walnut, broccoli, Brussels sprouts, cauliflower, peas, ginger, guava, jackfruit, lentils, apple, watermelon, corn, melon, mustard, turnip, nuts, egg, radish, cabbage and grapes. Beans were not included in this assessment since it should be consumed daily ${ }^{13,15}$.

6. Presence of sweets: considering that the maximum recommended intake of sugars and sweets is one serving a day ${ }^{13,15}$, a maximum of one serving was considered appropriate. This assessment included ready-to-eat preparations, such as chocolate milk, jelly, pudding, dulce de leche, cakes, and powdered fruit drinks with sugar as main ingredient.

\section{Presence of high-fat meats or deep-fried} foods: here, lunch and supper were assessed separately. This criterion was classified as appropriate when a maximum of $25 \%$ of the meats and hot side dishes offered during the day consisted of high-fat meats and deep-fried foods. High-fat meats were defined as meats with 50\% of their energy contents coming from fats, namely filet steak, flank, sparerib, cover steak, rib, organ meats, tenderloin, beef clod and short plate ${ }^{17}$.

8. Presence of foods and/or preparations with trans fatty acids: since there are no established upper safe limits for this nutrient ${ }^{18}$, the absence of foods and preparations with this type of fatty acid was considered appropriate.

All preparations in the menu were first classified according to each of the criteria above. For this purpose, the Brazilian Food Composition Table (Tabela Brasileira de Composição de Ali- mentos - TACO) ${ }^{19}$ and the nutrition facts labels of the processed foods were used. Next, the frequency of occurrence of the criteria expressed as percentage was determined for each day care center, considering the percentage adequacy of each one.

Food waste was quantified by the Plate Waste-Ingestion Index (PWI) given by the relationship between the Weight of the Plate Waste (WPW) and Weight of the Distributed Meal (WDM), and represented by the formula \% PWI= WPWx100/WDM ${ }^{7}$.

The weight of the distributed meals was determined by randomly collecting three servings of each food and/or preparation during distribution and calculating the mean amount served to each child. Next, the mean amount was multiplied by the number of children in each group. Second helpings were included in the calculations, thus giving the final weight of the distributed meals ${ }^{7}$.

The weights and/or measurements of each food and/or preparation was obtained, corresponding to the WPW served during breakfast, mid-morning snack, mid-afternoon snack and supper, when it consisted of soup only. However, for lunch and occasionally supper, the analysis considered the \% PWI per meal, because the foods and preparations were mixed on the plate?

The socioeconomic profiles of the children of the study institutions were determined by administering a questionnaire to their parents to determine the household income, which was determined by adding wages and other sources of income of all household members. The sum was expressed in Reais and converted to minimum salary units. The simple and percentage frequency distributions of the children's age, gender and socioeconomic class are described.

All data were input twice, and validated and analyzed by the statistical software Epi-Info 2000, version 3.4.3. 
The project was approved by Universidade Federal de São Paulo's Research Ethics Committee under protocol number 0442/10.

\section{RE S U L T S}

The socioeconomic characterization of the children enrolled in the study day care centers is shown in Table 1. Table 1 also shows that the gender distribution of the 366 children aged 12 to 36 months of the seven study day care centers was homogeneous. The household income of $62.8 \%$ of the families that use this service varies from one to three minimum salaries.
The meals were as follows: breakfast consisted of milk (pure, chocolate milk, cocoa composite milk or coffee composite milk) and bread (with margarine or jam or cream cheese (requeijão) alternating with plain cookies. The mid-morning snack consisted of a natural fruit juice with added sugar. Lunch consisted of rice and beans or pasta with beef, chicken or egg along with a raw salad and/or cooked vegetables, plus dessert (a fruit or sweet). The mid-afternoon snack consisted of only milk (pure, chocolate milk, cocoa milk composite or coffee milk composite). Supper was identical to lunch or consisted exclusively of soup and dessert (a fruit or sweet).

Table 1. Socioeconomic and demographic characteristics of the children attending public day care centers. São Paulo (SP), Brazil, 2010.

\begin{tabular}{|c|c|c|c|c|c|c|c|c|c|c|c|c|c|c|c|c|}
\hline \multirow{3}{*}{ Variable } & \multicolumn{16}{|c|}{ Day care centers } \\
\hline & \multicolumn{2}{|c|}{1} & \multicolumn{2}{|c|}{2} & \multicolumn{2}{|c|}{3} & \multicolumn{2}{|c|}{4} & \multicolumn{2}{|c|}{5} & \multicolumn{2}{|c|}{6} & \multicolumn{2}{|c|}{7} & \multicolumn{2}{|c|}{ Total } \\
\hline & $n$ & $\%$ & $n$ & $\%$ & $n$ & $\%$ & $n$ & $\%$ & $\mathrm{n}$ & $\%$ & $\mathrm{n}$ & $\%$ & $\mathrm{n}$ & $\%$ & $\mathrm{n}$ & $\%$ \\
\hline \multicolumn{17}{|c|}{ Age (months) } \\
\hline $12-24$ & 38 & 49.4 & 24 & 54.5 & 30 & 50.8 & 28 & 43.1 & 7 & 31.8 & 25 & 46.3 & 8 & 17.8 & 160 & 43.7 \\
\hline $24-36$ & 39 & 50.6 & 20 & 45.5 & 29 & 49.2 & 37 & 56.9 & 15 & 68.2 & 29 & 53.7 & 37 & 82.2 & 206 & 56.3 \\
\hline \multicolumn{17}{|l|}{ Gender } \\
\hline Female & 35 & 45.5 & 20 & 45.5 & 23 & 39.0 & 24 & 36.9 & 10 & 45.5 & 22 & 40.7 & 21 & 46.7 & 155 & 42.3 \\
\hline Male & 42 & 54.5 & 24 & 54.5 & 36 & 61.0 & 41 & 63.1 & 12 & 54.5 & 32 & 59.3 & 24 & 53.3 & 211 & 57.7 \\
\hline \multicolumn{17}{|c|}{$\begin{array}{l}\text { Household } \\
\text { income (MS)1 }\end{array}$} \\
\hline$<1.0$ & 1 & 1.3 & 6 & 13.6 & 7 & 12.1 & 5 & 7.8 & 1 & 4.5 & 2 & 3.8 & 3 & 6.7 & 25 & 6.9 \\
\hline $1.0-2.0$ & 23 & 29.9 & 26 & 59.1 & 19 & 32.8 & 21 & 32.8 & 7 & 31.8 & 21 & 39.6 & 19 & 42.2 & 136 & 37.5 \\
\hline $2.0-3.0$ & 26 & 33.8 & 5 & 11.4 & 18 & 31.0 & 18 & 28.1 & 2 & 9.1 & 10 & 18.9 & 13 & 28.9 & 92 & 25.3 \\
\hline$>3.0$ & 27 & 35.1 & 7 & 15.9 & 14 & 24.1 & 20 & 31.3 & 12 & 54.5 & 20 & 37.7 & 10 & 22.2 & 110 & 30.3 \\
\hline
\end{tabular}

Note: ${ }^{M}$ Minimum salary at the time of the study: $\mathrm{R} \$ 510.00$.

Table 2. Analysis of the menu offered in public day care centers: number of days in which each study criterion was appropriate. São Paulo (SP), Brazil, 2010

\begin{tabular}{|c|c|c|c|c|c|c|c|c|c|c|c|}
\hline \multirow{2}{*}{$\begin{array}{l}\text { Day care } \\
\text { center }\end{array}$} & \multirow{2}{*}{$\begin{array}{c}\text { Menu } \\
\text { days (n) }\end{array}$} & \multirow{2}{*}{ Fruits } & \multirow{2}{*}{ Vegetables } & \multirow{2}{*}{$\begin{array}{c}\text { Leafy } \\
\text { vegetables }\end{array}$} & \multirow{2}{*}{$\begin{array}{c}\text { Colors } \\
\text { (lunch/supper) }\end{array}$} & \multirow{2}{*}{ Sulfur } & \multirow{2}{*}{ Sweets } & \multirow{2}{*}{ Meats } & \multirow{2}{*}{$\begin{array}{c}\text { Trans fatty } \\
\text { acids }\end{array}$} & \multicolumn{2}{|c|}{ Adequacy by center } \\
\hline & & & & & & & & & & $\mathrm{n}$ & $\%$ \\
\hline 1 & 6 & 6 & 2 & 0 & 4 & 4 & 0 & 4 & 0 & 20 & 41.7 \\
\hline 2 & 6 & 5 & 0 & 2 & 3 & 4 & 0 & 3 & 0 & 20 & 41.7 \\
\hline 3 & 6 & 6 & 0 & 2 & 3 & 5 & 0 & 5 & 0 & 21 & 43.8 \\
\hline 4 & 6 & 6 & 0 & 5 & 0 & 0 & 0 & 6 & 0 & 17 & 35.4 \\
\hline 5 & 6 & 6 & 0 & 4 & 1 & 2 & 0 & 6 & 0 & 19 & 39.6 \\
\hline 6 & 6 & 6 & 0 & 6 & 0 & 4 & 0 & 6 & 0 & 26 & 54.2 \\
\hline 7 & 6 & 6 & 2 & 2 & 4 & 4 & 0 & 2 & 0 & 20 & 41.7 \\
\hline Adequacy $n$ by & 42 & 41 & 4 & 21 & 15 & 23 & 0 & 32 & 0 & 143 & \\
\hline Criterion \% & 100.0 & 97.6 & 9.5 & 50.0 & 35.7 & 54.8 & 0.0 & 76.2 & 0.0 & & 42.6 \\
\hline
\end{tabular}


140 | G LONGO-SILVA et al.

Table 3. Plate Waste-Ingestion Index (PWI)" of the different foods or preparations offered in public day care centers. São Paulo (SP), Brazil, 2010.

\begin{tabular}{|c|c|c|c|c|c|c|c|c|c|c|}
\hline \multirow{2}{*}{ Day care } & \multicolumn{10}{|c|}{ Plate waste-ingestion index (PWI) (\%) } \\
\hline & Milk ${ }^{1}$ & Bread & Cookies & Fruit juices & Full meal ${ }^{2}$ & Fruits & Sweets $^{3}$ & Milk ${ }^{4}$ & Soup & Total Mean \\
\hline 1 & 37 & 42 & 23 & 10 & 35 & 33 & 11 & 21 & 17 & 25 \\
\hline 2 & 49 & 62 & 51 & 4 & 35 & 26 & 19 & 21 & 15 & 34 \\
\hline 3 & 57 & 66 & 39 & 36 & 58 & 39 & 9 & 31 & no & 43 \\
\hline 4 & 37 & 24 & 50 & 19 & 49 & 51 & 11 & 28 & 35 & 34 \\
\hline 5 & 50 & 18 & 50 & 16 & 48 & 44 & 5 & 57 & no & 37 \\
\hline 6 & 77 & 33 & 59 & 17 & 31 & 27 & no & 41 & no & 41 \\
\hline 7 & 24 & 35 & 18 & 22 & 29 & 22 & no & 30 & 39 & 28 \\
\hline Total Mean & 47 & 40 & 41 & 17 & 41 & 35 & 11 & 33 & 27 & 34 \\
\hline
\end{tabular}

Note: $1 \%$ IR= Weight of the Plate Waste (WPW) x 100/Weight of the Distributed Food (WDF); 'Milk offered at breakfast, being either pure, chocolate milk, cocoa milk composite or coffee milk composite; 'Lunch and supper; ${ }^{3}$ Jelly, pudding, rice pudding, cake and processed sweet; ${ }^{4}$ Milk offered at the mid-afternoon snack, being either pure, chocolate milk, cocoa composite milk or coffee composite milk; no - food not offered on the study days.

The soups offered on the study days were vegetable, bean, chicken and vegetable, and pasta soups.

Table 2 shows the number of days in which each of the analyzed criteria occurred. The supply of fruits was adequate in nearly all study days. On the other hand, the supply of vegetables was inadequate in more than $90 \%$ of the days, and the amounts of leafy vegetables and high-sulfur foods met the expectations in only $50 \%$ of the study days. The supply of sweets and foods containing trans fatty acids in the menu was considerable.

Food waste, expressed as percentage of plate waste-ingestion, is shown in Table 3, showing that in all institutions and for all study foods, the amount of plate waste exceeded the acceptable limit of $10 \%$.

\section{DISCUSSION}

The supply of fruits was adequate because it was not in the menu of only one of the study days. Discordant results were found by Menegazzo et al. ${ }^{12}$, who found that fruits were offered in the menus of CEl for children aged two to six years in only $4,0 \%$ of the study days and by Neelon et al. ${ }^{20}$, who found that fruits were listed in the menus planned for children aged up to six years but were offered on only $14.4 \%$ of the study days.

Although the supply frequency was adequate, the amount of fruits offered may be inadequate, since PWI was 35\%, emphasizing the importance of encouraging fruit intake through nutrition education measures starting in early childhood. Meanwhile, fruit juices had a lower PWI (17\%). The ease with which juice can be consumed when compared with fruit, since it does not require chewing, may contribute to its better acceptance. On the other hand, juices contain fewer fibers and nutrients ${ }^{21}$.

The supply of vegetables (9.5\%) and raw leafy vegetables $(50.0 \%)$ was inadequate. This is worrisome since the intake of these foods in Brazil has been declining, with a reduction of 5.0 to $8.0 \%$ between the years of 2003 and 2008, which is even more pronounced in lower-income families ${ }^{22}$, the ones to which the study children belong.

The presence of vegetables, including raw leafy vegetables, varied from 0 to $100 \%$, emphasizing the absence of standardization or compliance with the menu. Hence, some institutions offer vegetables daily while others do not.

Meals were considered adequately colorful on $35.7 \%$ of the study days and color- 
monotonous meals were observed in the different day care centers $33.0 \%$ to $100.0 \%$ of the time. This variation may reflect the cook's creativity for preparing different foods and the need of training these professionals so that they may increase the attractiveness of a dish without changing the menu composition. The lunch and supper PWI was $41.0 \%$; although this datum is multicausal, it may be affected by meal appearance, which may prevent acceptance by the children ${ }^{15}$.

On $45.2 \%$ of the study days, too many high-sulfur foods were offered. Food with a high content of sulfur-containing amino acids increases the sensation of gastric discomfort because of gas production after the meals ${ }^{16}$.

Sweets were offered on all study days and institutions. This is worrisome because sugar intake is associated with a general reduction in diet quality, early-onset overweight and obesity ${ }^{23}$ and development of Non-Communicable Chronic Diseases (NCCD) and respective risk factors ${ }^{24}$. Additionally, excessive and frequent sugar intake promotes dental caries ${ }^{25}$, which is aggravated by the absence of tooth-brushing in the $\mathrm{CEl}$ routine.

This criterion includes processed foods, such as sweets, chocolate milk, pudding and jelly, and the literature shows that this situation is also seen at home. While studying the ages in which foods are introduced to children that attend day care centers, Toloni et al. ${ }^{26}$ found that more than $70 \%$ of the parents had offered sandwich cookies, candies, lollypops, chocolate and jelly before the child's first year of age. Hence, children should be discouraged from consuming excess sweets and added sugar.

Processed foods contain too much sodium and chronic sodium intake is associated with high blood pressure and mortality from cardiovascular diseases. Epidemiological studies offer consistent evidence that adult high blood pressure begins during childhood ${ }^{27}$.

The familiarity and appreciation of sweets by children is reflected by the lower PWI observed in this study, corresponding to only $11 \%$.
The supply of meats was appropriate in $76.2 \%$ of the days. On the other days, fat meats were offered. Fried foods were not offered, since the Department of School Food (DME) of the municipality of São Paulo recommends that this type of preparation should only be offered to children aged two years or more and at most, once every 15 days. A different reality is seen in Portuguese kindergartens: according to Lopes \& Roch ${ }^{28}, 21 \%$ of the monthly menus contain meals with some deep-fried component, and as many as $45.0 \%$ of the meals of some cafeterias contained deep-fried items. Concordantly, Erinosho et al. ${ }^{6}$ studied 40 day care centers in New York during one day and found that $6.7 \%$ of the study institutions served French fries.

Foods containing trans fatty acids were present in all menus, but it must be reemphasized that no safe upper intake limit has been established. The World Health Organization ${ }^{18}$ recommends that the maximum daily intake should not exceed $1 \%$ of the total energy intake. The present study prioritized the $\mathrm{TACO}^{19}$ for assessing this criterion since the information contained in nutrition facts labels regarding this substance is unreliable. According to the Regulamento Técnico de Porções de Alimentos Embalados Para Fins de Rotulagem Nutriciona ${ }^{29}$, the content of a nutrient can be expressed as "zero" or "absent" if the food contains less than or equal the amounts deemed insignificant. Hence, if a serving of a food contains $0.2 \mathrm{~g}$ or less of trans fatty acids, the manufacturer may omit it.

Regarding food waste, the mean PWI for day care centers varied from $25 \%$ to $43 \%$, and for foods and preparations from $11 \%$ to $47 \%$.

The foods that composed breakfast, namely milk, bread and cookies, were those with the highest PWI, namely $47 \%, 40 \%$ and $41 \%$, respectively. These percentages may be justified by the fact that, according to the literature, most children have breakfast at home ${ }^{30}$.

The plate waste associated with full meals (lunch and supper) was worrisome because only 
$60.0 \%$ of the food on the plate was consumed. While studying school meals in Portugal, Campos et al. ${ }^{31}$ found a mean PWI of $31.0 \%$, and a minimum PWI of $17.0 \%$. On the other hand, Martins et al. ${ }^{32}$ found that plate waste varied from 1.8 to $7.5 \%$ in public schools of Piracicaba, SP, Brazil.

Soups (vegetables, beans, chicken with vegetables, and pasta) were better accepted than full meals, with a PWI 34\% lower than that of full meals. Analogously, Martins et al. ${ }^{32}$ studied the acceptance of different preparations offered at school and found an acceptability of $90 \%$ for pasta soup. Although this is good from the waste viewpoint, the replacement of foods by soup should not be encouraged since soups have less flavor differentiation and taste stimulation, requires less chewing, and contains lower energy density ${ }^{15}$

The sensory characteristics of the menu may be influenced not only by the color monotony of these meals, but also by environmentallyrelated operational factors. According to the literature, food rejection increases when cafeterias are overcrowded and excessively noisy. In fact, it is known that an unpleasant eating environment affects eating behavior ${ }^{33}$. Moreover, food supply dynamics may reflect both the lack of motivation of the employees to improve meal acceptance and the difficulty of feeding young children during the meal period of the institution. It is noteworthy that each educator is responsible for the care and feeding of nine children ${ }^{1}$.

Nahikian-Nelms ${ }^{34}$ proposes important behaviors that educators should display during mealtime as a way to encourage eating and the formation of healthy eating habits, such as sitting at the table with the children, eating the same foods, not rushing the children, encouraging them to try the foods, not forcing them to eat, not using food as a prize, reward or punishment, having a pleasant conversation during the meal and creating opportunities for nutrition education during the meal.
Since the study group is under two years of age, assessing the factors that influence meal acceptance is difficult because during this period, children are beginning to learn the process of verbal communication, so food-related aversions, desires and sensations cannot be fully manifested $^{1}$. This may explain the high level of plate waste observed in the present study.

It is noteworthy that plate waste is responsible for unnecessary costs and violates social, ethical and environmental issues. Furthermore, it reflects the poor quality of meals, highlighting possible failures in menu development, determination of serving sizes and definition of nutritional requirements.

Under the light of this premise, the importance of a dietician in the staff is highlighted, since dieticians learned to implement and supervise the periodical assessment of the plate waste-ingestion index and to analyze and identify the causes of food waste, performing regular reviews of serving sizes, developing projects of food and nutrition education, and promoting social, ecological and environmental awareness ${ }^{9}$.

With respect to school food, dieticians should encourage educators to join forces, promote reflections and contribute to the acknowledgment of the school environment as a space for the development of food security, understood as the universal access to food in nutritionally appropriate quantity and quality to ensure health ${ }^{35}$.

In this sense, to control means to analyze, compare and asses the procedures and performance of food services, aiming to reduce waste and optimize productivity once the production processes are known. The results are productivity gains, guaranteed quality service, less waste and inexpensive meals. To be effective and complete, waste-reduction programs must aggregate behavioral changes, education, and, especially, awareness of food handlers, thereby engaging in a war against hunger and for citizenship. 


\section{CONCLUSION}

The present study found that the meals given to the children are low in vegetables, including leafy vegetables, and high in sweets, high-sulfur foods, fat meats and foods containing trans fatty acids. The meals are also monotonous in terms of colors.

Additionally, the PWI indicated high plate waste, since more than half of the food offered to the children was discarded. Hence, it is necessary to pay attention to the preparations and respective serving sizes, and to adopt new strategies for menu creation and planning, a critical step for controlling food waste.

\section{COLLABORATORS}

GL-SILVA helped to conceive, analyze and interpret the data, and write the article. MHA TOLONI helped to analyze and interpret the data. SSP RODRIGUES helped to analyze and interpret the data and in the critical review. AMCN ROCHA helped to analyze and interpret the data and in the critical review. JAAC TADDEl helped in the critical review and approval of the version to be published.

\section{REFEREN CES}

1. Taddei JAAC, Brasil ALD, Palma D, Moraes DEB, Ribeiro LC, Lopez FA. Manual crechEficiente: guia prático para educadores e gerentes. $2^{a}$ ed. Barueri: Minha Editora; 2008.

2. Instituto Nacional de Estudos e Pesquisas Educacionais Anísio Teixeira. Censo Escolar 2010. Brasília: INEP; 2010 [acesso 2012 mar 14]. Disponível em: <http://www.inep.gov.br/basica/censo/Escolar/ Sinopse/sinopse.asp $>$.

3. Brasil. Ministério da Educação. Fundo Nacional de Desenvolvimento da Educação. Resolução n 38, de 16 de julho de 2009. Brasília: MS; 2009 [acesso 2012 abr 4]. Disponível em: <http://www.asbran. org.br/sitenovo/arquivos/resolucao38.pdf $>$.

4. Brasil. Ministério da Saúde. Fundo Nacional de Desenvolvimento da Educação. Programas alimentação escolar: apresentação. Brasília: MS; 2011 [acesso 2012 abr 4]. Disponível em: <http://www. fnde.gov.br/index.php/programas-alimentacaoescolar>.

5. Longo-Silva G, Toloni MHA, Goulart RMM, Taddei JAAC. Avaliação do consumo alimentar em creches públicas e filantrópicas em São Paulo, Brasil. Rev Paul Pediatr. 2012; 30(1):35-41. doi: 10.1590/S010 3-05822012000100006.

6. Erinosho T, Dixon LB, Young C, Brotman LM, Hayman LL. Nutrition practices and children's dietary intakes at 40 child-care centers in New York. J Am Diet Assoc. 2011; 111:1391-97. doi: 10.1016/j.jada.2011.06.0 01.

7. Carver AF, Patton MB. Plate waste in a school lunch. I. Over-all waste. J Am Diet Assoc. 1958; 34(6):615-8.

8. Goulart RMM. Desperdício de alimentos: um problema de saúde pública. Integração. 2008 [acesso 2012 maio 18]; 54:285-8. <http://www.usjt.br/ proex/produtos_academicos/285_54.pdf>.

9. Conselho Federal de Nutricionistas. Resolução CFN n 380, de 9 de dezembro de 2005. Brasília: CFN; 2005 [acesso 2012 maio 10]. Disponível em: <http:/ / www.cfn.org.br/novosite/pdf/res/2005/res 380.pdf>.

10. Poulain JP, Proença RPC. O espaço social alimentar: um instrumento para o estudo dos modelos alimentares. Rev Nutr. 2003; 16(3):245-56. doi: 10.1590/ S1415-52732003000300002.

11. Veiros MB, Proença RPC. Avaliação qualitativa das preparações do cardápio em uma unidade de alimentação e nutrição: método AQPC. Nutr Pauta. 2003; 11(62):36-42.

12. Menegazzo M, Fracalossi K, Fernandes AC, Medeiros NI. Avaliação qualitativa das preparações do cardápio de centros de educação infantil. Rev Nutr. 2011; 24(2):243-51. doi: 10.1590/\$1415-527320 11000200005.

13. Brasil. Ministério da Saúde. Guia alimentar para a população brasileira: promovendo a alimentação saudável. Brasília: MS; 2006 [acesso 2012 maio 10]. Disponível em: <http://189.28.128.100/nutricao/ docs/geral/guia_alimentar_conteudo.pdf>.

14. Konstantyner T, Taddei JAAC, Oliveira MN, Palma $D$, Colugnati FAB. Riscos isolados e agregados de anemia em crianças frequentadoras de berçários de creches. J Pediatr. 2009; 85(3):209-16. doi: 10.15 90/S0021-75572009000300005.

15. Brasil. Ministério da Saúde. Dez passos para uma alimentação saudável. Guia alimentar para crianças menores de dois anos. Série A. Normas e manuais técnicos. 2ª ed. Brasília: MS; 2010 [acesso 2012 maio 10]. Disponível em: <http://189.28.128.100/ nutricao/docs/geral/enpacs_10passos.pdf>.

16. Reis NT. Nutrição clínica: sistema digestório. Rio de Janeiro: Rubio; 2003. 
144 | G LONGO-SILVA et al.

17. Philippi ST. Nutrição e técnica dietética. $2^{\mathrm{a}}$ ed. Barueri: Manole; 2006

18. World Health Organization. Preventing chronic diseases: A vital instrument. Geneva: WHO; 2005 [cited 2012 May 17]. Available from: <http://www. who.int/chp/chronic_disease_report/full_ report.pdf>.

19. Núcleo de Estudos e pesquisas em Alimentação. Tabela brasileira de composição de alimentos. $4^{\text {a }}$ ed. Campinas: Unicamp; 2011 [acesso 2012 maio 16]. Disponível em: <http://www.unicamp.br/nepa/ downloads/taco_4_edicao_ampliada_e_revisada. pdf?PH PSESSID=b8f2d017fa504c81ac8ac62eacc 27c0e>.

20. Neelon SEB, Copeland KA, Ball SC, Bradley L, Ward DS. Comparison of menus to actual foods and beverages served in North Carolina child-care centers. J Am Diet Assoc. 2010; 110(12):1890-5. doi: 10.1016/j.jada.2010.09.012.

21. Nicklas TA, O'Neil CE, Kleinman R. Association between $100 \%$ juice consumption and nutriente intake and weight of children aged 2 to 11 years. Arch Pediatr Adolesc Med. 2008; 162:557-65. doi: 10.1001/archpedi.162.6.557.

22. Instituto Brasileiro de Geografia e Estatística. Pesquisa de Orçamento Familiar 2008-2009. Aquisição alimentar domiciliar per capita. Rio de Janeiro: IBGE; 2010 [acesso 2012 abr 15]. Disponível em: <http://www.ibge.gov.br/home/estatistica/ populacao/condicaodevida/pof/2008_2009_ aquisicao/pof20082009_aquisicao.pdf>.

23. Marshall TA, Eichenberger Gilmore JM, Broffitt B, Stumbo PJ, Levy SM. Diet quality in young children is influenced by beverage consumption. J Am Coll Nutr. 2005 [cited 2011 Dec 19]; 24:65-75. Available from: <http://www.jacn.org/content/24/1/65. full.pdf+html>

24. Fung TT, Malik V, Rexrode KM, Manson JE, Willett WC, Hu FB. Sweetened beverage consumption and risk of coronary heart disease in women. Am J Clin Nutr. 2009 [cited 2012 Apr 14]; 89:1037-42. Available from: <http://www.ajcn.org/content/89/ 4/1037.full.pdf+html>.

25. Yabao RN, Duante CA, Velandria FV, Lucas M, Kassu A, Nakamori $\mathrm{M}$, et al. Prevalence of dental caries and sugar consumption among 6-12-y-old schoolchildren in La Trinidad, Benguet, Philippines. Euro J Clin Nutr. 2005; 59:1429-38.

26. Toloni MHA, Longo-Silva G, Goulart RMM, Taddei JAAC. Introdução de alimentos industrializados e de alimentos de uso tradicional na dieta de crianças de creches públicas no município de São Paulo. Rev Nutr. 2011; 24(1):61-70. doi: 10.1590/S14 15-52732011000100006

27. Costa FP, Machado SH. O consumo de sal e alimentos ricos em sódio pode influenciar na pressão arterial das crianças? Ciênc Saúde Coletiva. 2010; 15(1):1383-89. doi: 10.1590/S1413-812320100 00700048

28. Lopes A, Rocha A. Avaliação qualitativa das ementas dos jardins-de-infância e escolas do primeiro ciclo de Pombal. Aliment Humana. 2010; 16(1):44-58.

29. Brasil. Agência Nacional de Vigilância Sanitária. Resolução n 359, de 23 de dezembro de 2003. Regulamento técnico de porções de alimentos embalados para fins de rotulagem nutricional. Brasília: Anvisa; 2003 [acesso 2012 fev 20]. Disponível em: <http://e-legis.bvs.br/leisref/public/show Act. php?id=9058>

30. Freiberg CK. Avaliação nutricional de crianças menores de dois anos institucionalizadas em creches no município de São Paulo [mestrado]. São Paulo: Universidade de São Paulo; 2000.

31. Campos V, Viana I, Rocha A. Estudo dos desperdícios alimentares em meio escolar. Nutr Pauta. 2011; 60-4.

32. Martins RCB, Medeiros MAT, Ragonha GM, Olbi JH, Segatti MEP, Osele MR. Aceitabilidade da alimentação escolar no ensino público fundamental. Saúde Rev Piracicaba. 2004 [acesso 2012 maio 17]; 6(Suppl 13):71-8. Disponível em: <http://www. urbal.piracicaba.sp.gov.br/download/Sa\% FAde \%20em\%20Revista\%20-\%20Seguran \% E7a\%20Alimentar.pdf>.

33. World Health Organization. Food and nutrition policy for schools: A tool for the development of school nutrition programmes in the European region. Geneva: WHO; 2006 [cited 2012 Jan 5]. Available from: <http://www.schoolsforhealth.eu/ upload/WHO_tool_development_nutrition_ program.pdf>

34. Nahikian-Nelms M. Influential factor of caregiver behavior at mealtime: A study of 24 child-care programs. J Am Diet Assoc. 1997; 97:505-9. doi: 10.1016/S0002-8223(97)00130-2.

35. Goulart RMM, Banduk MLS, Taddei JAAC. Uma revisão das ações de nutrição e do papel do nutricionista em creches. Rev Nutr. 2011; 23(4):655-65. doi: 10.1590/S1415-52732010000400015.

Received on: 14/6/2012

Final version on: 30/10/2012 Approved on: 13/11/2012 